\title{
From Pathology to Diagnosis: A Symptom-Free Patient with a Rheumatoid Nodule in the Foot
}

\author{
Patolojiden Tanıya: Semptomsuz Bir Hastada Ayakta Romatoid Nodül \\ Ebru TAŞTEKİN, ${ }^{1}$ Murat BİRTANE, ${ }^{2}$ Serdar KILINÇ, ${ }^{2}$ Mert ÇİFTDEMİR, ${ }^{3}$ Ufuk USTA,,${ }^{1}$ Nurettin TAŞTEKİN ${ }^{2}$ \\ ${ }^{1}$ Department of Pathology, Medical Faculty of Trakya University, Edirne, Turkey; \\ ${ }^{2}$ Department of Physical Medicine and Rehabilitation, Medical Faculty of Trakya University, Edirne, Turkey; \\ ${ }^{3}$ Department of Orthopedics and Traumatology, Medical Faculty of Trakya University, Edirne, Turkey
}

Subcutaneous rheumatoid nodules (RNs) are most commonly seen superficial soft tissue lesions which occur in $20-30 \%$ of patients with rheumatoid arthritis (RA). The foot involvement is rare and only seen in about $1 \%$ of all rheumatoid nodules. In this article, we present a 39-yearold female case with a pathologically verified as $\mathrm{RN}$ in an uncommon localization with no clear clinical symptoms of RA at onset. The possible role of RNs in early RA was stressed in the patient presenting with inflammatory joint signs in the course of follow-up.

Key words: Early rheumatoid arthritis; foot; rheumatoid nodule.

Inflammation in the synovial joint lining and rheumatoid nodules (RNs) are characteristic lesions present in rheumatoid arthritis (RA). Rheumatoid nodules, which are in fact destructive granulomas, are most evident subcutaneously and are found in $20-30 \%$ of RA cases. ${ }^{[1,2]}$ Eser et al. ${ }^{[3]}$ reported that the frequency of RNs was $14.7 \%$ in a Turkish population with RA disease. This ratio was $15.3 \%$ in early RA, and the patients with $\mathrm{RN}$ seemed to have had a more aggressive course of disease. ${ }^{[4]}$ These nodules frequently occur on the extensor surfaces of the upper extremities, especially under the elbow ${ }^{[5,6]}$ and also occur at systemic sites such as the lungs and in heart valves where granulomatous destruction of connective tissue can result in more serious consequences. ${ }^{[7]}$
Subkutan romatoid nodüller $(\mathrm{RN})$, romatoid artritli (RA) hastaların \%20-30'unda sıklıkla görülen yüzeyel yerleşimli yumuşak doku lezyonlarıdır. Ayak tutulumu nadir olup, tüm romatoid nodüllerinin yaklaşık \%1'ini oluşturur. Bu yazıda, nadir görülen lokalizasyonda patolojik tanısı RN olarak doğrulanan, hastalığın başlangıcında RA klinik bulguları olmayan 39 yaşında bir kadın olgu sunuldu. Takiplerinde inflamatuvar eklem bulguları beliren hastada erken RA'da RN'lerin muhtemel rolü vurgulandı.

Anahtar sözcükler: Erken romatoid artrit; ayak; romatoid nodül.

Rheumatoid nodules have been regarded as one of the systemic lesions of RA and are probably initiated by immune complexes. ${ }^{[8]}$ Histologically, the $\mathrm{RN}$ is a granuloma in which activated macrophages are prominent. ${ }^{[9-11]}$

Although RNs are not frequently encountered in RA patients, their existence strongly indicates RA diagnosis. In fact, Gossec et al. ${ }^{[12]}$ reported their diagnostic sensitivity as $2.4 \%$ and their specificity as $100 \%$, and this is also true in cases of early RA.

Rheumatoid nodules did not appear as diagnostic criteria in 2010 American College of Rheumatology (ACR) classification for early RA. ${ }^{[13]}$ Here, we present a case with a pathologically verified $\mathrm{RN}$ in an uncommon

\footnotetext{
Received: August 12, 2011 Accepted: January 3, 2012

Correspondence: Ebru Taştekin, M.D. Trakya Üniversitesi Tıp Fakültesi Patoloji Anabilim Dalı, 22030 Edirne, Turkey.

Tel: +90 533 - 4126122 e-mail: ebrutastekin@hotmail.com

(C)2012 Turkish League Against Rheumatism. All rights reserved.
} 
localization with no clear clinical symptoms of RA at onset. However, joint inflammation appeared later in the course of follow-up, emphasizing the possible role of RNs in early RA when they are present.

\section{CASE REPORT}

A 39-year-old female patient applied to the Orthopedic Surgery Outpatient Polyclinics of Trakya University Hospital with pain and soft tissue swelling on the dorsal side of the left foot between the second and third metatarsal heads. These symptoms had lasted for more than a year.

The diameter of the localized swelling was $0.3 \mathrm{~cm}$. The ultrasonographic evaluation ordered by an orthopedist revealed a hypoechogenic mass resembling Morton's neuroma, and further magnetic resonance imaging (MRI) showed a cystic lesion. Conventional radiographs of the affected site showed no sign of arthritis. The mass, which was observed at the dorsum of the second and third metatarsal interval, was excised during surgical exploration with a part of its capsule and sent for pathological evaluation.

Histopathologic evaluation revealed some findings compatible with $\mathrm{RN}$, and the tissue was dirty yellowwhite in color when examined macroscopically. Microscopic evaluation showed papillary proliferation in the synovial epithelium, an increase in the synovial joint lining, a follicle forming intense lymphoplasmacytic inflammation in some areas under the epithelium, intra-tissue fibrin deposition, and increased vascularization around and swelling in the vascular endothelium. In the stroma of the subepithelial area, irregular fibrinoid necrotic foci could be seen, and there were nodules composed of palisading histiocytes with lymphocytes around them. Synovial epithelial hyperplasia, papillary growth, plasma cell-rich chronic inflammation, edema, and vascularization were also seen (Figure 1, 2).

After pathological evaluation, the patient was sent to the Rheumatology Outpatient Polyclinics of the Physical Medicine and Rehabilitation Department. Although the patient did not report any other symptoms, a careful, detailed symptom inquiry revealed obscure morning stiffness lasting for 30 minutes in both hands with no evident arthritis findings. No signs of arthritis were evident in conventional radiographs obtained from the Orthopedic Surgery Department. However, the laboratory evaluation revealed high $\mathrm{C}$-reactive protein (CRP) $(1.2 \mathrm{mg} / \mathrm{dL})$, a positive rheumatoid factor (RF) $(45.5 \mathrm{IU} / \mathrm{ml})$, anti-cyclic citrullinated protein antibodies (anti-CCP) (166 unit/ml), and antinuclear antibodies (ANA) in 1/100 dilution. The extractable nuclear antigens (ENA) profile was negative. We decided to follow the probable upcoming clinical course with no prescribed medication, and the patient was scheduled for a follow-up visit three months later.

Although the only existing complaint was a mass in the foot along with positive laboratory findings suggestive of RA at the first visit, the clinical picture became clearer at the three-month follow-up visit as the patient had morning stiffness in both hands lasting more than half an hour. Upon physical examination, there was symmetric swelling and tenderness at the second and third metacarpophalangeal joints. Wrist and hand radiographs were normal. The laboratory evaluation revealed the following: a positive serum RF of $62.9 \mathrm{IU} / \mathrm{ml}$, anti-CCP of $244.2 \mathrm{unit} / \mathrm{ml}$, CRP of
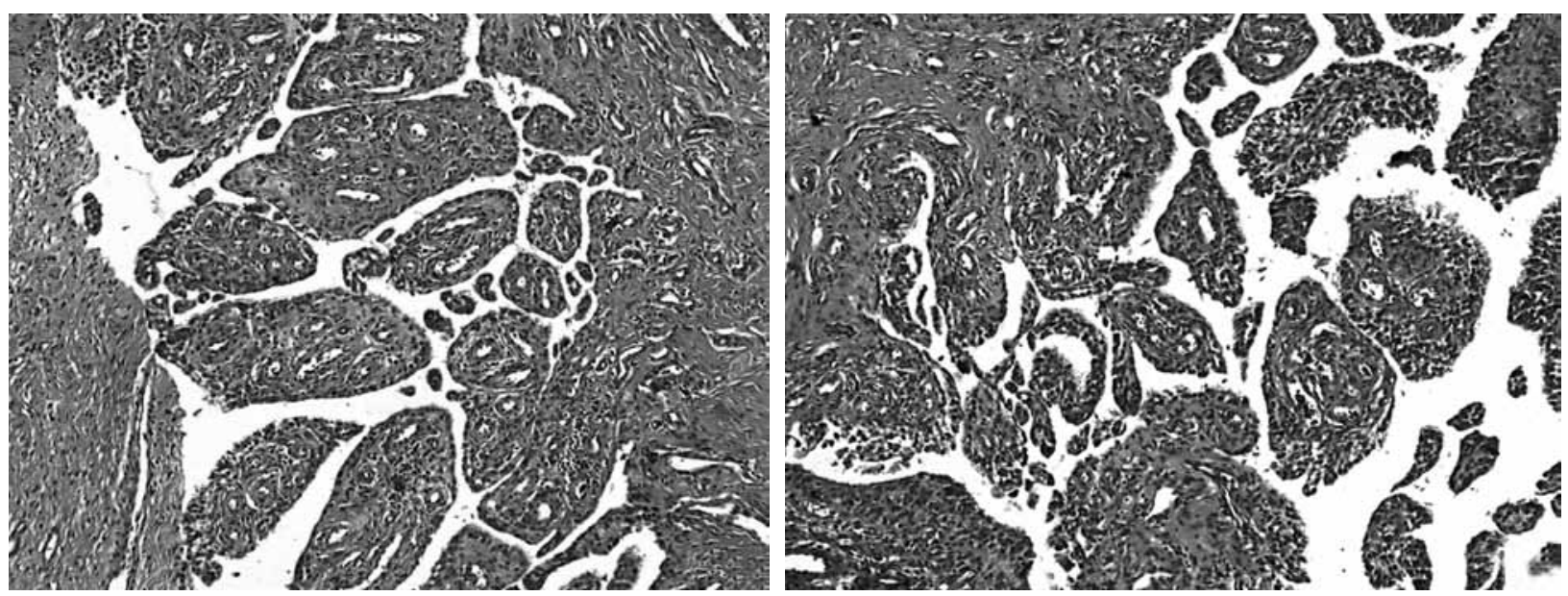

Figure 1. Papillary proliferation in the synovial epithelium, an increase in the lining, and a follicle forming intense lymphoplasmacytic inflammation in some areas under the epithelium (H-E x 50). 

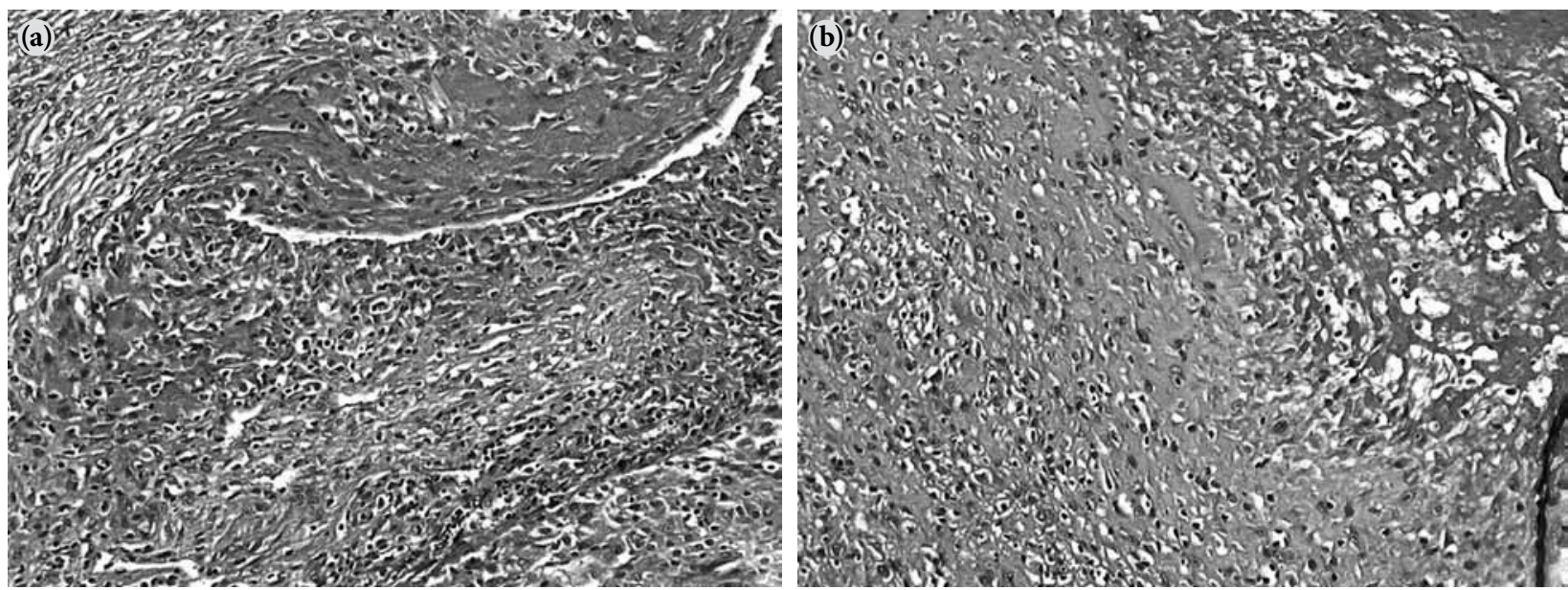

Figure 2. (a) Intra-tissue fibrin deposition, increased vascularization around and swelling in the vasculary endothelium (H-E x 50). (b) In the stroma of the subepithelial area, irregular fibrinoid necrotic foci can be seen, and there are nodules composed of palisading histiocytes with lymphocytes around them (H-E x 100).

$4.19 \mathrm{mg} / \mathrm{dL}$, and an erythrocyte sedimentation rate (ESR) of $36 \mathrm{~mm} /$ hour. In this instance, the patient was diagnosed as having RA according to the 2010 classification criteria, and the patient was treated with methotrexate ( $15 \mathrm{mg} /$ week) and folic acid ( $10 \mathrm{mg} /$ week). The symptoms improved markedly at the sixth week of treatment.

\section{DISCUSSION}

Subcutaneous RNs are the most common, superficial soft tissue lesions and occur in $20-30 \%$ of patients with RA. ${ }^{[14]}$ The presence of an RN is considered a sign of advanced disease and is usually seen in patients with a positive RF. ${ }^{[15]}$ The nodules are likely to occur in areas of repetitive microtrauma, especially at overlying, bony protuberances. ${ }^{[16]}$ Although the nodules occur in a broad range of locations throughout the body, they are commonly located in the superficial subcutaneous tissues, especially along the extensor surface of the upper extremities, but deeper areas such as the bursa, joints, tendons, or ligaments can also be involved. ${ }^{[6,9]}$

Foot involvement is rare and only about $1 \%$ of all RNs reportedly occur there. On the rare occasions where they do appear in the feet, they occur in the superficial soft tissues dorsally, adjacent to the Achilles tendon, in the toes, and in the heel pad. These nodules are generally asymptomatic, but they may lead to pain if they occur on the plantar aspect of the foot or on the palmar surface of the hand. ${ }^{[17,18]}$ Patients can have RNs at some uncommon sites, such as the dorsum of the foot, without any apparent clinical symptomatology of arthritis. This might provide a clue and warn the clinician regarding a possible emerging arthritic syndrome that is sometimes supported by positive laboratory findings, as was the case in this patient.

In this asymptomatic patient, the only parameter that made us suspect a rheumatic disease was the histopathologic feature of a solitary mass in the foot. After noticing that clue resembling an RN, the in-depth inquiry and subsequent laboratory findings led us to the very early RA diagnosis. Not very surprisingly, the patient displayed a characteristic clinical picture three months later. In this case, the main finding which triggered the diagnosis was the histopathologic analysis.

Rheumatoid nodules usually present clinically as a firm, flesh-colored, non-tender, freely movable mass. ${ }^{[10]}$ The worst complications are a breakdown of the overlying skin with a risk of infection and erosion in the adjacent bone. ${ }^{[19,20]}$ Pathologically, these lesions are granulomas with areas of central necrosis. The lesion's periphery is composed of palisading fibroblasts and histiocytes which lead to chronic inflammatory infiltration. ${ }^{[21]}$ Vascular inflammatory changes followed by necrosis are the main feature, and this necrosis occurs due to the large quantities of collagenases produced by the palisading cells. Other theories have suggested that trauma or possibly genetic factors may contribute to the formation. ${ }^{[7,14]}$ In this case, the RN was a solid mass with interspersed areas of central necrosis. It was composed histologically of chronic inflammatory cells surrounded by a palisade of fibroblasts and lymphocytes, and the central areas of necrosis contained deposits of fibrin. 
To be sure, such a nodule does not verify a diagnosis of RA, and in the clinical picture, it is very important to distinguish an RN from other types of nodules. The revelation of the clinical picture of RA and the laboratory findings helped us make the diagnosis in this case. In addition, new classification criteria for RA diagnosis was useful for recognizing RA at a very early stage. ${ }^{[13]}$ Parameters such as the involvement of four small joints symmetrically, abnormal levels of RF and anti-CCP, high acute phase reactants, and persistence of these symptoms for more than six months are satisfactory for an early diagnosis of RA. The absence of radiographic erosion alone is not enough to exclude RA. The abnormality of both RF and anti-CCP is already a very remarkable finding for RA with $97 \%$ specificity. ${ }^{[22]}$

It is well known that the presence of an $\mathrm{RN}$ is highly specific for RA diagnosis. In this asymptomatic case, we oriented our minds to the possibility of a rheumatological disease when the histopathologic features of a nodule exhibited an inflammatory character resembling a rheumatological etiology. The three-month follow-up confirmed our suspicion as clear symptomatology was revealed. Recent guidelines have emphasized the importance of joint involvement, serology, acute phase response, and the duration of symptoms in the diagnosis of early RA. However, some other findings, such as the $\mathrm{RN}$ seen in this case, can be helpful when RA is suspected in the very early phase before a clear clinical picture has been formulated.

\section{Declaration of conflicting interests}

The authors declared no conflicts of interest with respect to the authorship and/or publication of this article.

\section{Funding}

The authors received no financial support for the research and/or authorship of this article.

\section{REFERENCES}

1. Gómez MT, Polo AM, Romero AM, Gutiérrez JV, García GM. Rheumatoid nodulosis: report of two cases. J Eur Acad Dermatol Venereol 2003;17:695-8.

2. Couret M, Combe B, Chuong VT, Leroux JL, Blotman F, Sany J. Rheumatoid nodulosis: report of two new cases and discussion of diagnostic criteria. J Rheumatol 1988;15:1427-30.

3. Eser F, Garip Y, Bodur H. Extraarticular manifestations in Turkish patients with rheumatoid arthritis: impact of EAMs on the health-related quality of life in terms of disease activity, functional status, severity of pain, and social and emotional functioning. Rheumatol Int 2012;32:1521-5.
4. da Mota LM, Laurindo IM, dos Santos Neto LL. Demographic and clinical characteristics of a cohort of patients with early rheumatoid arthritis. Rev Bras Reumatol 2010;50:235-48. [Article in English, Portuguese]

5. Hertling D, Kessler R.M. Elbow and forearm. In: Hertling D, Kessler RM, editors. Management of common musculoskeletal disorders. Philadelphia: Lippincott Williams \& Wilkins; 2006. p. 357-90.

6. Sayah A, English JC 3rd. Rheumatoid arthritis: a review of the cutaneous manifestations. J Am Acad Dermatol 2005;53:191-209.

7. Matteson EL, Cohen MD, Conn DL. Rheumatoid arthritis: clinical features-systemic involvement. In: Klippel JH, Dieppe PA, editors. Rheumatology. St. Louis: Mosby Year Book; 1994. p. 5.1-5.8.

8. Sokoloff L, McCluskey RT, Bunim JJ. Vascularity of the early subcutaneous nodule of rheumatoid arthritis. AMA Arch Pathol 1953;55:475-95.

9. Ziff M. The rheumatoid nodule. Arthritis Rheum 1990;33:761-7.

10. Palmer DG, Hogg N, Highton J, Hessian PA, Denholm I. Macrophage migration and maturation within rheumatoid nodules. Arthritis Rheum 1987;30:728-36.

11. Hessian PA, Highton J, Kean A, Sun CK, Chin M. Cytokine profile of the rheumatoid nodule suggests that it is a Th1 granuloma. Arthritis Rheum 2003;48:334-8.

12. Gossec L, Combescure C, Rincheval N, Saraux A, Combe B, Dougados M. Relative clinical influence of clinical, laboratory, and radiological investigations in early arthritis on the diagnosis of rheumatoid arthritis. Data from the French Early Arthritis Cohort ESPOIR. J Rheumatol 2010;37:2486-92.

13. van der Linden MP, Knevel R, Huizinga TW, van der Helm-van Mil AH. Classification of rheumatoid arthritis: comparison of the 1987 American College of Rheumatology criteria and the 2010 American College of Rheumatology/European League Against Rheumatism criteria. Arthritis Rheum 2011;63:37-42. doi: 10.1002/ art.30100.

14. Kaye BR, Kaye RL, Bobrove A. Rheumatoid nodules. Review of the spectrum of associated conditions and proposal of a new classification, with a report of four seronegative cases. Am J Med 1984;76:279-92.

15. Combe B, Sany J. Extraarticular manifestations during methotrexate therapy for rheumatoid arthritis. J Rheumatol 1995;22:790.

16. Mine T, Tanaka H, Taguchi T, Ihara K, Ishida Y, Sugitani T, Kawai S. A giant rheumatoid nodule. Clin Rheumatol 2004;23:467-9.

17. Oloff-Solomon J, Oloff LM, Jacobs AM. Rheumatoid nodulosis in the foot: a variant of rheumatoid disease. J Foot Surg 1984;23:382-5.

18. Canter KG. Rheumatoid nodules in the foot. J Foot Surg 1978;17:35-7.

19. Chiu DW, Ross S, Salvatori RW. Cystic bone lesion in the fifth metatarsal with subcutaneous rheumatoid nodule. J Am Podiatr Med Assoc 1992;82:471-4. 
20. Dorfman HD, Norman A, Smith RJ. Bone erosion in relation to subcutaneous rheumatoid nodules. Arthritis Rheum 1970;13:69-73.

21. Highton J, Theewis W, Palmcr DG. Characteristics of patients with rheumatoid arthritis attending the Dunedin rheumatology clinic. Proc Univ Otago Med Sch 1982;60:4-6.
22. Jansen $A L$, van der Horst-Bruinsma I, van Schaardenburg D, van de Stadt RJ, de Koning MH, Dijkmans BA. Rheumatoid factor and antibodies to cyclic citrullinated Peptide differentiate rheumatoid arthritis from undifferentiated polyarthritis in patients with early arthritis. J Rheumatol 2002;29:2074-6. 